\title{
PENGARUH KONSENTRASI ASAM KLORIDA DAN LAMA PERENDAMAN TERHADAP SIFAT FISIK DAN KIMIA GELATIN TULANG IKAN TUNA (Thunnus albacare)
}

\author{
Masrukan $^{1}$, Yudi Pranoto ${ }^{2}$, Umar Santoso $^{2}$
}

\begin{abstract}
Type A gelatin was extracted from partial hydrolysis of collagen from tuna fish bone. The experiment was conducted to determine the effect of hydrochloride acid solution and soaking time on physical and chemical properties of tuna fish bone gelatin and to determine optimum conditions for extraction of tuna fish bone gelatin which is based on the highest yield and gel strength. The experiment used randomized complete block design (RCBD) with two factors. The first factor was concentration of hydrochloric acid consisting of 3 level $(1,3$, and $5 \% \mathrm{v} / \mathrm{v})$ and the second factor was soaking time $(24,48$, and 72 hours). The results showed that concentration of hydrochloric acid and soaking time significantly affect at the physical and chemical properties of tuna fish bone gelatin. The optimum condition obtained the treatment of gelatin was concentration of hydrochloric acid 3\% and soaking time 72 hours. Physical and chemical properties of gelatin from tuna fish bone, which is 120.37 gram Bloom gel strength; viscosity $4.75 \mathrm{cP}$; melting point $20.37^{\circ} \mathrm{C}$; color was yellowish brown, moisture content $11.85 \%$, protein content $80.90 \%$; f fat content $2.73 \%$ and ash content $8.12 \%$.
\end{abstract}

Keywords: gelatin, hydrochloride, soaking time, physical and chemical properties

\begin{abstract}
ABSTRAK
Gelatin tipe A diperoleh dari hidrolisis parsial kolagen dari tulang ikan tuna. Penelitian ini bertujuan untuk mengetahui pengaruh konsentrasi larutan asam klorida dan lama perendaman terhadap sifat fisik dan kimia gelatin tulang ikan tuna dan untuk mengetahui kondisi optimum ekstraksi gelatin tulang ikan tuna yang didasarkan pada rendemen dan nilai kekuatan gel tertinggi. Penelitian dilaksanakan menggunakan rancangan acak lengkap dengan dua faktor. Faktor pertama yaitu konsentrasi larutan asam klorida terdiri dari 3 taraf $(1,3$, dan $5 \% \mathrm{v} / \mathrm{v}$ ), sedangkan faktor kedua adalah lama perendaman juga dengan 3 taraf ( 24,48 , dan 72 jam). Dari hasil penelitian menunjukan konsentrasi asam klorida dan lama perendaman berpengaruh nyata terhadap sifat fisik dan kimia gelatin tulang ikan tuna. Kondisi optimum yang diperoleh pada ekstraksi gelatin adalah konsentrasi asam klorida $3 \%$ dan lama perendaman $72 \mathrm{jam}$. Sifat fisik dan kimia gelatin dari tulang ikan tuna, yaitu kekuatan gel 120,37 gram Bloom; viscositas $4,75 \mathrm{cP}$; titik leleh gelatin tulang ikan tuna $20,37^{\circ} \mathrm{C}$; warna antara kuning hingga kuning kecoklatan, kadar air 11,85\%; kadar protein 80,90 \%.; kadar lemak 2,73 \%; dan kadar abu 8,12\%;
\end{abstract}

Kata kunci: gelatin, asam klorida, lama perendaman, sifat fisik, sifat kimia, tulang ikan tuna

\section{PENDAHULUAN}

Gelatin adalah koloid hidrofilik yang diperoleh melalui hidrolisis parsial kolegen dari kulit, tulang, sendi, dan jaringan pengikat hewan (Krotca, 1994). Gelatin memiliki berat molekul 22.000-250.000 (Omri, 2002). Kandungan asam amino gelatin terdiri dari glisin (26-34\%), prolin (10-18\%), hidroksiprolin (7-15\%), alanin (8-11\%), arginin (8-9\%), asam aspartat (6-7\%), dan asam glutamate (10-12\%) (Poppe, 1997).

Di Indonesia lebih dari $60 \%$ total produksi gelatin digunakan oleh industri pangan, sekitar $20 \%$ industri fotografi dan $10 \%$ oleh industri farmasi dan kosmetik (Peranginangin, 2006). Untuk produk pangan gelatin dapat dimanfaatkan sebagai bahan penstabil (stabilizer), pembentuk gel (gelling agent), pengikat (binder), pengental

\footnotetext{
${ }^{1}$ Program Studi Teknologi Pangan Fakultas Teknologi Pertanian Universitas Widya Mataram Yogyakarta ${ }^{2}$ Departemen Teknologi Pangan dan Hasil Pertanian Fakultas Teknologi Pertanian Universitas Gadjah Mada Email: mrukan@gmail.com
} 
(thickener), pengemulsi (emulsifier), perekat (adhesive), whipping agent, dan pembungkus makanan yang bersifat dapat dimakan (edible coating). Dalam bidang farmasi gelatin digunakan untuk produksi kapsul lunak, cangkang kapsul, dan tablet (Poppe, 1997).

Data terakhir menunjukkan bahwa produksi gelatin tiap tahun di seluruh dunia mencapai 326.000 ton. Gelatin yang berasal dari kulit babi menempati urutan terbesar, yaitu $46 \%$, kulit sapi $29,4 \%$, tulang sapi $23,1 \%$, dan sumber lainnya hanya $1,5 \%$ (GME, 2008). Adanya hukum syariat Islam yang mewajibkan pengikutnya untuk mengkonsumsi sesuatu yang jelas kehalalannya serta isu-isu lain dari hewan mamalia terutama sapi tentang maraknya berita tentang penyakit sapi gila ( $m a d$ cow disease) atau Bovine Spongioform Encephalopathy (BSE), maka ditelitilah gelatin yang diekstrak dari kolagen ikan sebagai salah satu bahan aditif alternatif yang dapat diterima seluruh masyarakat (Haug, 2004).

Kolagen yang berasal dari ikan berpotensi menjadi sumber bahan baku utama pada pembuatan gelatin. Tulang dan kulit ikan sangat potensial sebagai sumber gelatin karena mencakup 10-20\% dari total bobot tubuh ikan. Kandungan kolagen pada tulang ikan keras (teleostei) berkisar 15-17\%, sedangkan pada tulang ikan rawan (elasmobranch) berkisar 22-24\% (Purwadi, 1999).

Ekstraksi gelatin dari tulang ikan tuna merupakan usaha pemanfaatan limbah industri pengolahan ikan yaitu dari industri pengalengan dan fillet. Sebelum diekstraksi, terlebih dahulu dilakukan persiapan dengan cara merendam tulang ke dalam larutan asam mapun basa. Asam yang digunakan adalah asam yang aman dan tidak menususk hidung (Choi dkk., 2000). Hal ini didukung oleh penelitian Cho (2000) bahwa rendemen gelatin dari proses asam menggunakan asam klorida lebih tinggi dibandingkan dengan asam sulfat dan asam sitrat.
Dari permasalahan yang telah dikemukakan diatas, maka akan dilakukan penelitian mengenai ekstrasi gelatin dari tulang ikan tuna. Tujuan penelitian ini adalah untuk mengetahui pegaruh konsentrasi larutan asam klorida dam lama perendaman terhadap sifat fisik dan kimia gelatin dari tulang ikan tuna.

\section{METODE PENELITIAN \\ Bahan baku dan alat}

Tulang ikan tuna segar diperoleh dari distributor pengolahan ikan tuna "Fresh Tuna" Sonopakis Yogyakarta. Sedangkan bahan untuk ekstraksi meliputi asam klorida, air, aquades, kertas saring, dan kertas alumunium foildiperoleh dari Laboratorium Kimia dan Biokimia FTP UGM.

Alat-alat yang digunakan untuk ekstraksi gelatin meliputi nampan plastik, pisau, blender, panci, kompor listrik, gelas ukur, timbangan, thermometer, refrigerator, dan cabinet dryer. Peralatan untuk karakterisasi gelatin meliputi botol timbang, desikator, spatula, penjepit, oven, timbangan analit, pipet, autoclave, vortex, muffle furnacel, kompor listrik, erlenmeyer, unit distilasi mikro Kjeldahl, unit ekstraksi soxhlet, universal testing machine (UTM), viskosimeter (VT-04), waterbath, homogenizer, dan seperangkat peralatan HPLC (Simadzu).

\section{Tahap persiapan}

Tulang ikan tuna dibersihkan dari sisa daging beserta durinya. Tulang ikan tuna yang telah bersih kemudian dilakukan perebusan dengan suhu $70{ }^{\circ} \mathrm{C}$ selama $25-30$ menit. Tulang ikan tuna dipotong-potong menjadi ukuran kecil $(2-3 \mathrm{~cm})$ untuk memperbesar luas permukaanya. Selanjutnya dilakukan perendaman asam klorida (1, 3, dan 5\% $\mathrm{v} / \mathrm{v})$.dengan lama perendaman $(24,48$, dan 72 jam) dengan perbandingan tulang ikan tuna dan asam klorida $(1: 4 \quad \mathrm{w} / \mathrm{v})$. Setelah perendaman tulang ikan tuna dicuci dengan air mengalir hingga mencapai $\mathrm{pH}$ mendekati 
netral sehingga diperoleh tulang ikan tuna lunak (ossein).

\section{Tahap ekstraksi}

Tulang ikan tuna diekstraksi dengan memasukan tulang ikan tuna ke dalam erlenmeyer yang diisi aquades dengan perbandingan tulang ikan tuna dan aquades adalah 1:3. Selanjutnya dipanaskan di dalam waterbath pada suhu $80 \pm 5^{\circ} \mathrm{C}$ selama 6 jam. Hasil ekstraksi kemudian disaring menggunakan kertas saring dengan pompa vacuum hingga diperoleh filtrat. Kemudian filtrat dikeringkan ke dalam cabinet dryer pada suhu $55{ }^{0} \mathrm{C}$ selama $35-48$ jam. Setelah kering dilakukan penghancuran dan pengayakan (20 mesh) sehingga diperoleh serbuk gelatin.

\section{Rancangan Percobaan}

Rancangan percobaan yang digunakan dalam penelitian ini adalah rancangan acak lengkap yang disusun secara faktorial. Faktor pertama adalah konsentrasi asam klorida $(1,3$, dan $5 \% \mathrm{v} / \mathrm{v})$. Sedangkan faktor kedua adalah lama perendaman $(24,48$, dan 72 jam). Untuk mengetahui pengaruh perlakuan terhadap parameter yang dianalisis maka dilakukan uji keragaman, apabila terdapat beda nyata dilakukan uji Duncan dengan jenjang nyata 5\% (Gomez, 1984). Analisis rendemen dan kekuatan gel tertinggi digunakan sebagai parameter untuk menentukan kondisi optimum ekstraksi gelatin tulang ikan tuna yang selanjutnya dibandingkan sifat fisik dan kimianya dengan gelatin komersial serta gelatin Sigma

\section{Analisis Percobaan}

\section{Viskositas}

Larutan gelatin dengan konsentrasi 6,67 $\%(\mathrm{~b} / \mathrm{b})$ disiapkan dengan akuades kemudian diukur viskositasnya menggunakan alat viscometer vt-4. Pengukuran dilakukan pada suhu $60{ }^{\circ} \mathrm{C}$. Nilai viskositas dinyatakan dalam satuan cP (British Standard 757 1975).

\section{Titik leleh}

Larutan gelatin dengan konsentrasi 6,67 $\%(\mathrm{~b} / \mathrm{b})$ disiapkan dengan akuades. Sampel dinkubasi pada suhu $10^{\circ} \mathrm{C}$ selama $17 \pm 2$ jam. Pengukuran titik leleh dilakukan dengan cara memanaskan gel gelatin dalam waterbath. Diatas gel gelatin tersebut diletakkan gotri dan ketika gotri jatuh ke dasar gel gelatin, maka suhu tersebut merupakan suhu titik leleh (Suryaningrum dan Utama 2002).

\section{Kekuatan gel}

Larutan gelatin dengan konsentrasi $6,67 \%(\mathrm{w} / \mathrm{v})$ disiapkan dengan aquades kemudian dipanaskan dalam waterbath suhu $60^{\circ} \mathrm{C}$ selama 30 menit. Selanjutnya larutan dituangkan dalam standar bloom jar (botol dengan diameter 58-60 $\mathrm{mm}$ dengan tinggi 85 $\mathrm{mm}$ ) lalu didiamkan dalam suhu ruang selam 30 menit. Langkah selanjutnya diinkubasi pada suhu $9-10^{\circ} \mathrm{C}$ selama $17-18$ jam. Selanjutnya diukur menggunakan alat universal texture mechine (UTM Zwich Z 0,5) pada kecepatan probe $0,5 \mathrm{~mm} /$ detik dengan kedalaman $4 \mathrm{~mm}$ dengan diameter plunger yang digunakan adalan $12,7 \mathrm{~mm}$. kekuatan gel dinyatakan dalam satuan gram bloom. Perhitungan kekuatan gel dalam satuan (gram Bloom) menggunakan rumus :Kekuatan gel (gram Bloom) : gaya maks $\left(\mathrm{g} / \mathrm{mm}^{2}\right)$ x luas permukaan plunger $\left(\mathrm{mm}^{2}\right)$ luas permukaan plunger dengan $(\mathrm{r}=6,35)$ adalah $126,728 \mathrm{~mm}^{2}$. Kekuatan gel dikoreksi ( kadar protein gelatin dianggap $87,5 \%$ ) dengan persamaan gram Bloom $=$ gram Bloom x $(87,5 /(100$ - kadar air\% - kadar abu\%)) $)^{2}$ (Muyonga et al., 2003).

\section{Profil asam amino Kondisi HPLC}

\begin{tabular}{ccc}
\hline $\mathrm{T}$ & Flow & B\% \\
\hline 0 & 1,5 & 30 \\
3 & 1,5 & 30 \\
25 & 1,5 & 100 \\
25,02 & 1,5 & 30 \\
\hline
\end{tabular}


Kolom : Eurospher 100-5 C18, 250 x 4,6 $\mathrm{mm}$ with precolumn $\mathrm{P} / \mathrm{N}: 11115 \mathrm{Y} 535$

Eluen : $\mathrm{A}=$ Buffer asetat $0,01 \mathrm{M} \mathrm{pH} \mathrm{5,9}$

$\mathrm{B}=$ Metanol: buffer asetat $0,01 \mathrm{M} \mathrm{pH}$ 9,5:THF 80: 15: 5,Ext $\quad: 340$, Em: $450 \mathrm{~nm}$

Progam gradient

\section{HASIL DAN PEMBAHASAN}

Rendemen

Rendemen merupakan salah satu parameter yang penting dalam menilai efektif tidaknya proses produksi gelatin. Rendemen dihitung berdasarkan perbandingan antara gelatin serbuk yang dihasilkan dengan bobot tulang ikan tuna sebagai bahan baku. Rerata rendemen gelatin disajikan pada Tabel 1.

Tabel 1. Rendemen gelatin tulang ikan tuna (\%)

\begin{tabular}{|c|c|c|c|}
\hline \multirow{2}{*}{$\begin{array}{l}\text { Konsentrasi } \\
\text { asam klorida } \\
(\%)\end{array}$} & \multicolumn{3}{|c|}{ Lama waktu perendaman (jam) } \\
\hline & 24 & 48 & 72 \\
\hline 1 & $5,59 \pm 0,14^{\mathrm{a}}$ & $5,59 \pm 0,94^{\mathrm{a}}$ & $5,49 \pm 0,62^{\mathrm{a}}$ \\
\hline $\begin{array}{l}3 \\
5\end{array}$ & $\begin{array}{l}10,56 \pm 0,47^{\mathrm{de}} \\
10,41 \pm 0,19^{\mathrm{d}}\end{array}$ & $\begin{array}{l}10,74 \pm 0,49^{\mathrm{de}} \\
9,56 \pm 0,67^{\mathrm{b}}\end{array}$ & $\begin{array}{l}11,24 \pm 0,41^{\mathrm{e}} \\
8,61 \pm 0,39^{\mathrm{c}}\end{array}$ \\
\hline
\end{tabular}

Keterangan: rerata yang diikuti dengan huruf yang berbeda pada baris atau kolom menunjukkan ada beda nyata pada jenjang nyata $5 \%$.

Berdasarkan hasil penelitian, rendemen gelatin tertinggi dihasilkan oleh perlakuan konsentrasi asam klorida 3\% dengan lama perendaman 72 jam, yaitu sebesar 11,24\%, sedangkan rendemen gelatin terendah dihasilkan oleh perlakuan konsentrasi 1\% dengan lama perendaman 72 jam, yaitu sebesar 5,49\%. Pada perlakuan konsentrasi asam klorida 3\% dengan lama perendaman 72 jam merupakan perlakuan yang optimum bagi ion $\mathrm{H}^{+}$menghidrolisis kolagen dari rantai triple helix menjadi rantai tunggal, sehingga rendemen gelatin yang diperoleh lebih banyak pada saat ekstraksi dengan perebusan.

Semakin tinggi konsentrasi asam klorida maka struktur kolagen akan lebih terbuka yang berakibat semakin banyak kolagen yang terhidrolisis sehingga akan semakin banyak yang dapat diekstraksi ketika proses perebusan. Menurut Chamidah dan Elita (2002), larutan asam berfungsi untuk menghidrolisis kolagen sehingga mempermudah kelarutanya dalam air panas saat ekstraksi gelatin, hal ini terjadi karena struktur kolagen terbuka akibat beberapa ikatan dalam molekul proteinya terlepas. Akan tetapi pada konsentrasi Pada konsentrasi 5\% semakin lama waktu perendaman nilai rendemen gelatin dari tulang ikan tuna semakin menurun hal ini diakibatkan $\mathrm{H}^{+}$yang berlebih disertai suhu yang tinggi akan mendenaturasi kolagen yang terhidrolisis pada saat perendaman dengan larutan asam klorida. Konsentrasi asam yang berlebih dan suhu yang tinggi menimbulkan adanya hidrolisis lanjutan sehingga sebagian gelatin turut terdegradasi pada saat ektraksi dengan perebusan sehingga menyebabkan turunnya jumlah gelatin.

Rendahnya rendemen juga berkaitan dengan berkuranganya kolagen yang terekstrak selama tahap pencucian serta berkaitan dengan hidrolisis kolagen yang tidak sempurna (Jamilah dan Harvinder, 2002). Rendemen dari gelatin ikan lebih rendah dari gelatin mamalia, yaitu berkisar 6-19\%. Kisaran rendemen yang luas disebabkan adanya perbedaan kandungan kolagen pada bahan bakunya (Karim dan Bhat, 2009).

\section{Kekuatan gel}

Kekuatan gel adalah salah satu parameter dari tekstur suatu bahan dan merupakan gaya untuk menghasilkan deformasi tertentu (De Man, 1989). Kekuatan gel didefinisikan sebagai besarnya kekuatan yang diperlukan oleh probe untuk menekan gel sampai pada kedalaman $4 \mathrm{~mm}$ dengan kecepatan $0,5 \mathrm{~mm} / \mathrm{s}$. Rerata nilai kekuatan gel gelatin tulang ikan tuna dapat dilihat pada Tabel 2.

Berdasarkan pengujian yang dilakukan terhadap gelatin tulang ikan tuna, diperoleh bahwa pada perlakuan konsentrasi asam klorida 3\% dengan lama perendaman 72 jam didapatkan hasil kekuatan gel tertinggi, yaitu 
sebesar 120,37 gram Bloom. Sedangkan pada konsentrasi asam klorida 1\% dengan lama perendaman 24 jam diperoleh nilai kekuatan gel yang rendah, yaitu 47,98 gram Bloom. Hal ini diakibatkan konsentrasi asam klorida yang rendah pada saat perendaman sehingga belum terjadi hidrolisis yang sempurna pada kolagen, hal ini ditunjukkan oleh kondisi ossein yang masih agak keras setelah direndam dengan larutan asam klorida.

Tabel 2. Nilai kekuatan gel gelatin tulang ikan tuna (gram Bloom)

\begin{tabular}{|c|c|c|c|}
\hline \multirow{2}{*}{$\begin{array}{c}\text { Konsentrasi } \\
\text { asam } \\
\text { klorida } \\
(\%)\end{array}$} & \multicolumn{3}{|c|}{ Lama waktu perendaman (jam) } \\
\hline & 24 & 48 & 72 \\
\hline 1 & $47,98 \pm 0,35^{\mathrm{a}}$ & $80,99 \pm 1,76^{b}$ & $112,50 \pm 1,2$ \\
\hline 3 & $\begin{array}{l}115,71 \pm 0,9 \\
5^{\mathrm{e}}\end{array}$ & $\begin{array}{l}112,96 \pm 2,7 \\
3^{\mathrm{d}}\end{array}$ & $120,37 \pm 0,9$ \\
\hline 5 & $\begin{array}{l}115,78 \pm 0,5 \\
1^{\mathrm{e}}\end{array}$ & $\begin{array}{l}104,58 \pm 1,0 \\
2^{\mathrm{d}}\end{array}$ & $\begin{array}{l}101,31 \pm 0,3 \\
5^{\mathrm{c}}\end{array}$ \\
\hline
\end{tabular}

Keterangan: rerata yang diikuti dengan huruf yang berbeda pada baris atau kolom menunjukkan ada beda nyata pada jenjang nyata $5 \%$.

Stainsby (1977), mengemukakan bahwa pembentukan gel gelatin terjadi karena pengembangan molekul gelatin pada waktu pemanasan. Adanya panas akan membuka ikatan-ikatan pada molekul gelatin dan cairan yang semula bebas mengalir menjadi terperangkap di dalam struktur tersebut, sehingga terbentuk gel yang kental.

Gelatin ikan pada umumnya mempunyai kekuatan gel kurang dari 270 gram Bloom. Sedangkan gelatin sapi dan babi umumnya mempunyai kekuatan gel sekitar 200-240 gram Bloom. Cho dkk., (2005) melaporkan kekuatan gel pada gelatin dari kulit ikan tuna sebesar 426 gram Bloom. Sedangkan kekuatan gel gelatin pada ikan tilapia berkisar antara 128 sampai 273 gram Bloom (Jamilah dan Harvinder, 2002).

\section{Viskositas}

Viskositas gelatin tulang tuna disajikan pada Tabel 3. Berdasarkan hasil penelitian nilai viskositas tertinggi pada perlakuan perendaman larutan asam klorida 3\% dengan lama perendaman 48 jam, yaitu sebesar $5,0 \mathrm{cP}$, sedangkan nilai viskositas terendah diperoleh gelatin dengan perlakuan konsentrasi 5\% dengan lama perendaman 24 jam, yaitu sebesar 2,5 cP. Nilai viscositas gelatin tulang ikantuna hasil penelitian berkisar antara 2,5-5 cP. Nilai viscositas ini masuk dalam kisaran nilai viscositas SNI yaitu antara 2,0-7,5 cP (Wahyuni dan Rosmawaty, 2003). Rerata viskositas gelatin tulang ikan tuna bisa dilihat pada Tabel 3.

Tabel 3. Viskositas gelatin tulang ikan tuna (cP)

\begin{tabular}{|c|c|c|c|}
\hline \multirow{2}{*}{$\begin{array}{c}\text { Konsentrasi } \\
\text { asam klorida } \\
(\%)\end{array}$} & \multicolumn{3}{|c|}{ Lama waktu perendaman (jam) } \\
\hline & 24 & 48 & 72 \\
\hline 1 & $3,2 \pm 0,11$ & $3,5 \pm 0,11^{\mathrm{c}}$ & $3,75 \pm 0,50$ \\
\hline 3 & $5 \pm 0,20^{\mathrm{d}}$ & $\begin{array}{l}4,75 \pm 0,05 \\
\mathrm{~d}\end{array}$ & $\underset{\mathrm{d}}{4,75 \pm 0,06}$ \\
\hline 5 & $\begin{array}{l}3,5 \pm 0,12 \\
c\end{array}$ & $2,5 \pm 0,01^{\mathrm{a}}$ & $3 \pm 0,38^{\mathrm{b}}$ \\
\hline
\end{tabular}

Keterangan: rerata yang diikuti dengan huruf yang berbeda pada baris atau kolom menunjukkan ada beda nyata pada jenjang nyata $5 \%$.

Keberadaan mineral yang tergolong jenis abu dalam jumlah yang terlalu banyak mempengaruhi karakteristik gel gelatin, seperti kekuatan gel, titik leleh, dan viskositas, terutama bila mineral-mineral tersebut berasosiasi dengan gugus reaktif dari molekul gelatin, seperti gugus $\mathrm{OH}, \mathrm{COOH}$, dan $\mathrm{NH}_{2}$. Viskositas gelatin juga dipengaruhi oleh distribusi molekul gelatin dalam larutan serta berat molekul gelatin. Avena dkk., (2006) menyatakan bahwa semakin kecil berat molekul dari gelatin juga menyebabkan distribusi molekul gelatin dalam larutan semakin cepat sehingga menghasilkan nilai viskositas yang rendah.

\section{Titik leleh}

Titik leleh gelatin adalah suhu dimana gelatin yang berbentuk gel tepat mencair setelah dipanaskan secara perlahan-lahan (Stainsby 1977). Berdasarkan pengujian yang 
dilakukan terhadap gelatin, diketahui bahwa pada perlakuan konsentrasi larutan asam klorida 3\% dengan lama perendaman 24 jam didapatkan nilai titik leleh tertinggi, yaitu sebesar $20,37^{\circ} \mathrm{C}$. Sedangkan konsentrasi asam klorida $1 \%$ dan lama perendaman 24 jam diperoleh nilai titik leleh yang rendah

Tabel 4. Titik leleh gelatin tulang ikan tuna

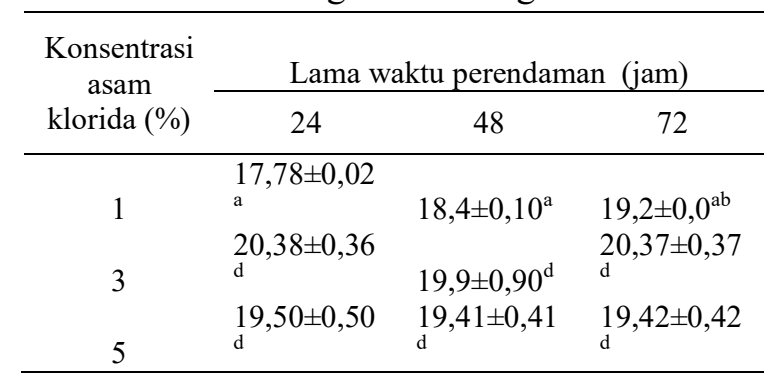

Keterangan: rerata yang diikuti dengan huruf yang berbeda pada baris atau kolom menunjukkan ada beda nyata pada jenjang nyata $5 \%$.

Pada konsentrasi asam klorida 3 dan 5\% semakin lama perendaman tidak menunjukan pengaruh yang berbeda nyata terhadap nilai titik leleh gelatin $(\alpha: 0,05)$. Gilsenen dan RossMurphy (2000) menyatakan bahwa ada keterkaitan antara titik leleh dengan distribusi berat mokul gelatin serta komposisi asam amino. Gelatin dengan bobot molekul rendah meleleh pada suhu rendah dibandingkan dengan gelatin yang mempunyai berat molekul tinggi. Semakin tinggi berat molekul gelatin akan berpengaruh terhadap viskositas dan titik leleh yang semakin tinggi juga (Karim dan Bhat, 2009).

Penelitian Utama (1997) menyebutkan bahwa bila kandungan asam amino glisin dan hidroksiprolin lebih rendah, maka ikatan hidrogen dari gelatin terhadap air dalam larutan akan rendah sehingga menyebabkan titik leleh gelatin menjadi rendah.

\section{Warna}

Warna gelatin tulang ikan tuna, gelatin komersial, dan gelatin Sigma bisa dilihat pada Tabel 5. Warna gelatin tulang ikan tuna mempunyai warna kecerahan yang rendah bila dibandingkan dengan gelatin komersial. Sedangkan warna kekuningan dari gelatin tulang ikan tuna relatif hampir mendekati dari gelatin komersial. Kecerahan warna gelatin yang dihasilkan akan memudahkan penggunaan gelatin karena tidak akan berpengaruh pada produk akhir yang ditambah gelatin. Selain itu warna gelatin yang cerah, tidak memerlukan bahan tambahan pangan atau perlakuan khusus untuk mencerahkan warna agar tidak merubah warna produk yang ditambah gelatin.

Tabel 5. Nilai kecerahan (L), kemerahan (a), dan kekuningan (b) dari gelatin

\begin{tabular}{lccc}
\hline \multirow{1}{*}{ Gelatin } & \multicolumn{3}{c}{ Hasil pengujian } \\
\cline { 2 - 4 } & $\mathrm{L}$ & $\mathrm{a}$ & $\mathrm{b}$ \\
\hline $\begin{array}{l}\text { Gelatin tulang ikan } \\
\text { tuna }\end{array}$ & 55,03 & 14,3 & 27,67 \\
$\begin{array}{l}\text { Gelatin komersial } \\
\text { (unknown) }\end{array}$ & 79,93 & 5,93 & 20,03 \\
$\begin{array}{l}\text { Gelatin Sigma } \\
\text { (porcine) }\end{array}$ & 60,5 & 11,93 & 29,80 \\
\hline
\end{tabular}

Keterangan: *): Gelatin tulang ikan tuna dengan perlakuan perendaman asam klorida $3 \%$, dan waktu perendaman $72 \mathrm{jam}$.

Buckle (1987) menyatakan pengeringan menyebabkan perubahan warna pada bahan menjadi kecoklatan karena reaksi browning non-enzimatis. Warna gelatin yang dilihat, selain dipengaruhi karena proses pengeringan juga dipengaruhi oleh warna alami yang ada pada tulang ikan tuna yang terikut pada saat ekstraksi gelatin.

\section{Profil asam amino}

Wards dan Courts (1977) menyatakan bahwa gelatin mengandung 19 jenis asam amino yang dihubungkan dengan ikatan peptida membentuk rantai polimer yang panjang. Menurut Astawan (2002) rendahnya kandungan asam amino glisin dan hidroksiprolin pada gelatin tulang ikan dapat mengakibatkan rendahnya titik leleh gelatin. Hasil pengujian komposisi asam amino dapat dilihat pada Tabel 6 . 
Charley (1982) menyatakan bahwa susunan asam amino gelatin hampir sama dengan kolagen, dimana glisin sebagai asam amino utama dan merupakan $2 / 3$ dari seluruh asam amino yang menyusunnya, 1/3 asam amino yang tersisa diisi prolin dan hidroksiprolin. Gelatin tulang ikan tuna mempunyai asam amino glisin yang lebih tinggi bila dibandingkan dengan gelatin dari kulit nila $(23,55 \%)$ serta gelatin dari ikan cod (17\%) (Munyoga et al., 2003).

Tabel 6. Komposisi asam amino gelatin tulang ikan tuna

\begin{tabular}{lc}
\hline \multicolumn{1}{c}{ Jenis asam amino } & Jumlah $(\%)$ \\
\hline Asam aspartat & 0,09 \\
Asam glutamat & 2,28 \\
Asparagin & 0,14 \\
Serin+Sistein & 1,34 \\
Glutamin & \\
Histidin & 0,25 \\
Glysin+ Threonin & 87,20 \\
Alanin & 3,54 \\
Arginin & 0,18 \\
Tyrosin & 1,34 \\
Methionin+ \\
thryptophan & 0,31 \\
Valin & 0,79 \\
Phenilalanin & 0,09 \\
Isoleusin & 1,30 \\
Leusin & 1,01 \\
Lysin & 0,02 \\
\hline
\end{tabular}

Pada gelatin yang diuji ditemukan hanya sedikit asam amino triptopan yang merupakan asam amino esensial, dan hal inilah yang menyebabkan gelatin dikatakan sebagai protein yang kandungan gizinya tidak lengkap. Triptopan merupakan salah satu asam amino esensial yang dibutuhkan oleh tubuh (Glicksman, 1969). Oleh karena itu penggunaannya sebagai bahan baku industri pangan, gelatin tulang ikan tuna hendaknya dikombinasikan dengan bahan pangan yang banyak mengandung triptopan, sehingga kekurangan asam amino tersebut dapat tertutupi.

\section{KESIMPULAN}

Konsentrasi asam klorida 3\% dengan lama perendaman 72 jam merupakan kondisi optimum proses ekstraksi gelatin dari tulang ikan tuna yang didasarkan pada rendemen dan nilai kekuatan gel tertinggi.

Karakteristik fisik gelatin tulang ikan tuna, yaitu rendemen sebesar 11,24\%, viskositas 4,75 cP, nilai kekuatan gel 102,12 gram Bloom, titik leleh sebesar $20,37^{\circ} \mathrm{C}$, serta mempunyai warna kuning-kuning kecoklatan. Karakteristik kimia gelatin tulang ikan tuna; kadar air 11,85\%, kadar protein 80,90\%, kadar lemak 2,73\%, dan kadar abu 8,12\%. Komposisi asam amino gelatin tulang ikan tuna adalah glisin+treonin $87,2 \%$, alanin $3,54 \%$, tyrosin $1,34 \%$, isoleusin $1,3 \%$, leusin $1,01 \%$, lisin $0,02 \%$,valin $0,79 \%$, arginin $0,18 \%$.

Hasil penelitian menunjukkan bahwa konsentrasi larutan asam klorida dan lama perendaman berpengaruh nyata $(\alpha: 0,05)$ terhadap rendemen, kekuatan gel, viscositas, dan titik leleh gelatin tulang ikan tuna.

\section{DAFTAR PUSTAKA}

Apriyantono, A., Fardiaz, D., Puspitasari, N.L., Yasni, S., Budiyanto, S. 1989. Analisis Pangan. IPB Press. Bogor.

Astawan, M., Hariyadi, P., Mulyani, A. 2002. Analisis Sifat Reologi Gelatin dari Kulit Ikan Cucut. Jurnal Teknologi dan Industri Pangan. Vol XIV. No. 1

Avena-Bustillos RJ, Olsen CW, Olson DA, Chiou B, Yee E, Bechtel PJ, McHugh LH. 2006. Water Vapor Permeability Of Mamalian and Fish Gelatin Films. Journal of Food Science. Vol 71 (4):202-207.

British Standard 757. 1975. Sampling and Testing of Gelatin. Di Dalam Imeson. 1992. Thikcening and Gelling Agents for Food. Academic Press, New York

Buckle KA, Edwars RA, Fleet GH, Wotton M. 1987. Ilmu Pangan., Penerjemah: 
Purnomo $\mathrm{H}$ dan Adiono, Penerbit Universitas Indonesia. Jakarta. Terjemahan dari: Food Science.Charley, H. 1982. Encyclopedia of Food Science and Technology. Vol. 2. John Wiley and Sons, New York.

Chamidah, A. dan Elita Ch. 2002. Pengaruh Pengolahan Terhadap Kualitas Gelatin Kulit Ikan Hiu. Seminar Nasional PATPI. ISBN:979-95249-6-2, Malang.

Choi, S.S., Regenstein, J.M. 2000. Physicochemical and Sensory Characteristic of Fish Gelatin. Journal Food Science. 65 (2): 194 199.

Cho, S.M, Y.S. Gu, S.B. Kim. 2005. Extracting Optimization and Phisycal Properties Of Tallow Tuna ( Thunnus albacare) Skin Gelatin Compared To Mammalian Gelatin.Food Hydocolloid 19:221-229.

De Man, J.M. 1997. Kimia Makanan. Penerjemahkan Padmawinata, K. ITB Press, Bandung.

GME. 2008. Gelatin manufacure of Europe. http:/www.gelatine.org/en/gelatin/overv iew/127.htm (acces date March 15, 2008).

Haugh, I.J., Draget,K.I.,and Smidsrod,O.2004. Physical and Rheological Properties of fish Gelatin Compared To Mammalian Gelatin. Food Hydrocolloids, 18, 203213.

Jamilah, B and K.G. Harvinder. 2002. Properties of Gelatin from Skins Of Fish Black Tilapia (Oreochromis mosambicus) and Red Tilapia (Oreochromis niloticai). Food Chemirtyr. Vol. 77, 81-84.

Junianto, Kiki Haetami, Ine Maulina, 2006. Produksi Gelatin Dari Tulang Ikan dan Pemanfaatannya Sebagai Bahan Dasar Pembuatan Cangkang Kapsul. UNPAD. Bandung.
Geltech. 2007. What is Gelatin. http://www.Geltech.com/whatisgelatin.h tml

Gilsenen, P.M. and S.B. Murphy. 2000. Rheological Characterization of Gelatin From Mammalian and Marine Source. Food Hydrocolloid. Vol, 14 191-195.

Glicksman, M. 1969. Gum Technology in Food Industry. Academic Press, New York.

Karim, A.A, and Bhat, R, 2009. Fish Gelatin: Properties, Challenge, and Aspect As An Alternative To Mammalian Gelatins. Food Hydrocolloid. Vol. 23, 563-576.

Krotcha,J.M., Baldwin,E.A. and NisperosCarrido,M.O. (1994). Edible Coating and Films To Improve Food Quality. Technomic Publishing Co. Inc. Lancaster. Pennsylvania.

Leiner, P.B. 2006. The Physical and Chemical Properties of Gelatin. http:///www.pbgelatin.com.

Munyonga et al., 2003. Extraction and Physico-Chemical Characterisation of Nile Perch (Lates niloticus) Skin and Bone Gelatin. Food Hydrocolloids 18 (2004) 581-592.

Norland Product. 2003. Fish Gelatin. http://www.norlandprod.com/techrpts.ht $\mathrm{ml}$.

Omri, 2002. Gelatin Processing. National Organic Standard Board Technical Advisory Panel Review, USDA National Organic progam.

Poppe, J. 1997. Gelatin. Di dalam A. Imeson (ed). Thickening and Gelling Agent For Food. Academic Press, New York.

Purwadi, T. 1999. Pengkajian Mutu dan Tekno-Ekonomi Perekat dari Tulang Ikan. IPB. Bogor.

Stainsby, G. 1987. Gelatin Gel. In, A.M. Person, T.R. Dutson dan A.J. Bayle. Advance Meat Research Newyork. 
Suryaningrum, T.D. dan B. S. D. Utomo. 2002. Petunjuk Analsis Rumput Laut dan Hasil Olahannya. Pusat Riset Pengolahan Produk dan Sosial Ekonomi Perikanan dan Kelautan. Jakarta.

Utama, H. 1997. Gelatin Bikin Heboh. Jurnal Halal LPPOM-MUI No. 18: 10-12

Wahyuni, M. dan Rosmawaty P. 2003. Perbaikan Daya Saing Industri Pengolahan Perikanan Melalui Pemanfaatan Limbah Non Ekonomis Ikan Menjadi Gelatin. Departemen Kelautan dan perikanan RI.

Ward, A.G., Courts, A. 1977. The Science and Technology of Gelatin. Academic Press, New York.

Winarno, F.G. 2002. Kimia Pangan dan Gizi. P.T. Gramedia Pustaka Umum, Jakarta. 